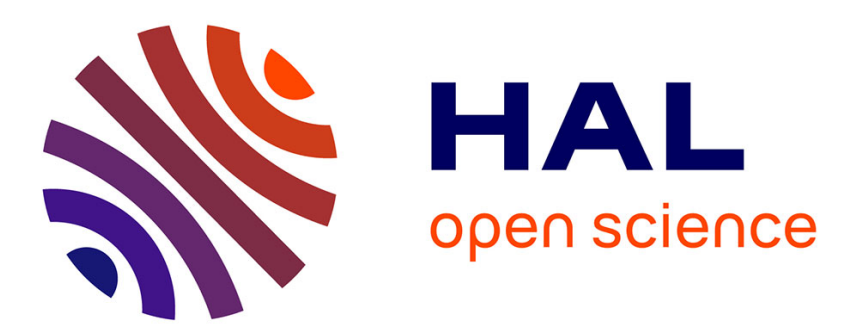

\title{
The Effect of Sintering Conditions on the Power Loss Characteristics of Mn-Zn Ferrites for High Frequency Applications
}

\author{
Y. Han, J. Suh, M. Shin, S. Han
}

\section{- To cite this version:}

Y. Han, J. Suh, M. Shin, S. Han. The Effect of Sintering Conditions on the Power Loss Characteristics of Mn-Zn Ferrites for High Frequency Applications. Journal de Physique IV Proceedings, 1997, 07 (C1), pp.C1-111-C1-112. 10.1051/jp4:1997133 . jpa-00255080

\section{HAL Id: jpa-00255080 https://hal.science/jpa-00255080}

Submitted on 1 Jan 1997

HAL is a multi-disciplinary open access archive for the deposit and dissemination of scientific research documents, whether they are published or not. The documents may come from teaching and research institutions in France or abroad, or from public or private research centers.
L'archive ouverte pluridisciplinaire HAL, est destinée au dépôt et à la diffusion de documents scientifiques de niveau recherche, publiés ou non, émanant des établissements d'enseignement et de recherche français ou étrangers, des laboratoires publics ou privés. 


\title{
The Effect of Sintering Conditions on the Power Loss Characteristics of Mn-Zn Ferrites for High Frequency Applications
}

\author{
Y.H. Han, J.J. Suh, M.S. Shin* and S.K. Han* \\ Sung Kyun Kwan University, 300 Chunchun-Dong, Suwon, Korea \\ * Isu Ceramic, 112-4 Banpo-Dong, Suhcho-Ku, Seoul, Korea
}

\begin{abstract}
The sintering temperature significantly changed the microstructure and effected the power loss behavior at the frequency range over $100 \mathrm{kHz}$. The best power loss characteristics at $100 \mathrm{kHz}-200 \mathrm{mT}$ and $500 \mathrm{kHz}-50 \mathrm{mT}$ were observed in the samples sintered at $1300^{\circ} \mathrm{C}$ and $1250^{\circ} \mathrm{C}$, respectively. Those results indicated that the power loss depended on the grain size, electrical resistivity and density of sintered cores. To maintain the stoichiometry at the sintering condition, the ferrite cores were processed on the isocomposition lines within the spinel phase boundary when being cooled. The zinc vapor pressure as well as the oxygen partial pressure was controlled. The high zinc loss condition had an adverse effect on the microstructure of the sintered core surface and degraded the power loss characteristics.
\end{abstract}

\section{INTRODUCTION}

$\mathrm{Mn}-\mathrm{Zn}$ Ferrite has long been selected as a material of choice due to its high saturation magnetization and low power loss for high frequency applications. The current research activity has concentrated on the high frequency low loss materials development for switching mode power supply. Since the power output increases with switching frequency, the high frequency operation is imperative to reduce the size of transformers. The switching frequency has been increased upto $1 \mathrm{MHz}$ at which the eddy current loss dominates the overall power loss ${ }^{2}$. To reduce the total power loss, both hysteresis loss and eddy current loss should be concurrently suppressed by employing the available processing techniques. For the higher frequency applications, the more precise control of microstructure as well as chemistry control is required to lower both hysteresis loss and eddy current loss.

Although the original chemical formula of $\mathrm{Mn}-\mathrm{Zn}$ ferrites is determined by the starting materials, the chemistry of sintered core is normally deviated from the initial composition. The ionic states of transition metal elements are subjected to change with oxygen partial pressure during sintering and cooling process. Furthermore zinc vaporizes with reducing atmosphere at high temperature. The zinc vaporization develops an exaggerated grain growth which deteriorates magnetic properties. In this study, the effect of sintering conditions on the power loss characteristics will be discussed in terms of sintering temperature, oxygen partial pressure and zinc loss.

\section{EXPERIMENTAL}

The sample with a composition of $52 \mathrm{~mol} \% \mathrm{Fe}_{2} \mathrm{O}_{3}, 37 \mathrm{~mol} \% \mathrm{MnO}$ and $11 \mathrm{~mol} \% \mathrm{ZnO}$ was prepared by a conventional ceramic processing technique. The ingredient raw materials were mixed in a ball mill and then spray-dried to minimize the separation during drying. Calcined powder was pulverized with additives of $400 \mathrm{ppm} \mathrm{CaO}$ and $100 \mathrm{ppm} \mathrm{SiO}_{2}$ and spray-dried with some binder for granulation. The powder was formed into a toroidal shape under uniaxial pressure of $1 \mathrm{ton} / \mathrm{cm}^{2}$, resulted in a dimension of $3.0 \mathrm{~cm}$ o.d., $2.0 \mathrm{~cm}$ i.d. and $1 \mathrm{~cm}$ height. Binder was carefully burnt out in air with slow heating rate. Cores were then sintered at various temperatures from $1200^{\circ} \mathrm{C}$ to $1350^{\circ} \mathrm{C}$ in a tube furnace with zinc loss control as well as with oxygen partial pressure. The oxygen partial pressure was controlled to satisfy one of the oxygen activity lines given by Morineau and Paulus(atmosphere parameter $=7.8$ and slope $=14540$ ) ${ }^{2}$. Electrical conductivity of a rectangular bar was measured at room temperature by four point dc technique. Core loss was measured by an Iwatsu BH analyzer(SY8232).

\section{RESULTS AND DISCUSSION}

\subsection{Effect of sintering temperature}

Fig. 1 shows the power loss at $80^{\circ} \mathrm{C}, 100 \mathrm{kHz}-200 \mathrm{mT}$ and $500 \mathrm{kHz}-50 \mathrm{mT}$ as a function of sintering temperatures. The power loss decreases gradually with sintering temperature and shows minimum values at $1300^{\circ} \mathrm{C}$ and $1250^{\circ} \mathrm{C}$ for $100 \mathrm{kHz}$ and $500 \mathrm{kHz}$, respectively. The density, grain size and electrical resistivity are plotted as a function of sintering temperatures in Fig. 2. The density and grain size increase with sintering temperature while the electrical resistivity decreases with temperature. In other words, the electrical resistivity decreases as the grain size increases. This implies that the grain boundary 
area contributes to the overall resistivity and forms an electrically insulating layer.

The power loss of $\mathrm{Mn}-\mathrm{Zn}$ ferrites consists of hysteresis loss and eddy current loss for the power applications. The eddy current loss is considered a more important loss characteristic for the high frequency applications, which is proportional to $\mathrm{d}^{2} / \rho$ where $\mathrm{d}$ and $\rho$ represent grain size and resistivity, respectively. The grain size and resistivity on Fig. 2 explain why the power loss minimum at $500 \mathrm{kHz}$ occurs at the lower sintering temperature than at $100 \mathrm{kHz}$. However, chemical homogeneity, high density with uniform grain size and reduction of grain boundary stress are required to reduce the hysteresis loss ${ }^{3}$. Those requirements for the lower hysteresis loss would have an adverse effect on the eddy current loss. Comparing the power loss characteristics on Fig. 1 with the physical properties on Fig. 2, the lower resistivity and the larger grain size resulted from the higher sintering temperature indicate that the eddy current loss is less dominant at $100 \mathrm{kHz}$ than at $500 \mathrm{kHz}$.

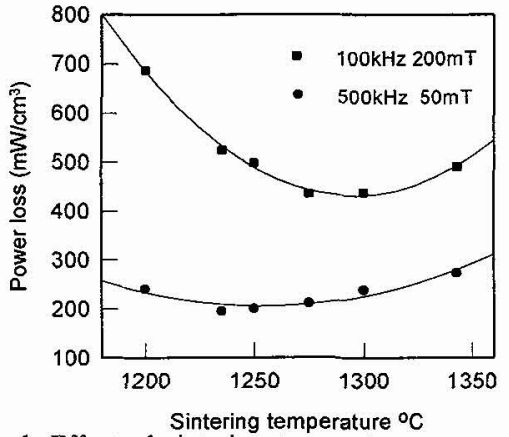

Fig. 1. Effect of sintering temperature on power loss at $100 \mathrm{kHz}, 500 \mathrm{kHz}$ and $80^{\circ} \mathrm{C}$.

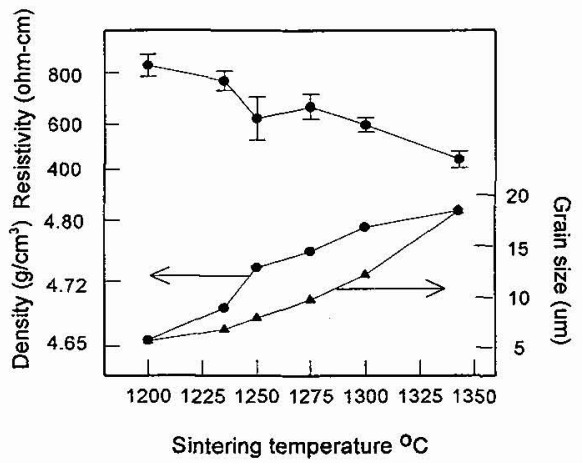

Fig. 2. Effect of sintering temperature on resistivity, density and grain size.

\subsection{Effect of zinc vapor control}

Zinc volatilization as well as cation nonstoichiometry due to oxygen partial pressure is one of the most troublesome processing problems for reproducible production of $\mathrm{Mn}-\mathrm{Zn}$ ferrites. Fig. 3 shows the surface morphology of ferrite cores sintered under a normal zinc loss condition. Deep grooves with a dimension of spray-dried granule were observed on the surface while they were avoided with control of zinc loss either by suppressing the $\mathrm{Zn}$ volatilization from the core surface or by providing the sintering area with zinc vapor. Fig. 4 shows the power loss characteristics at three different conditions such as high zinc loss, medium zinc loss and low zinc loss. The lowest power loss was observed on the sample with minimum zinc loss. The high zinc loss significantly degraded the core surface and increased the power loss. The toroidal cores with minimum zinc loss showed the power loss of $250 \mathrm{~mW} / \mathrm{cm}^{3}$ at $60^{\circ} \mathrm{C}$ and $100 \mathrm{kHz}-200 \mathrm{mT}$ as shown in Fig. 4, and a pronounced second peak maximum in the permeability-temperature curve. Tsunekawa reported a similar result of the highest permeability value of the second peak which was obtained after etching to remove the degraded surface areas ${ }^{4}$. It is thus believed that the suppression of zinc volatilization is an essential sintering condition for the high frequency low loss characteristics of $\mathrm{Mn}-\mathrm{Zn}$ ferrites.

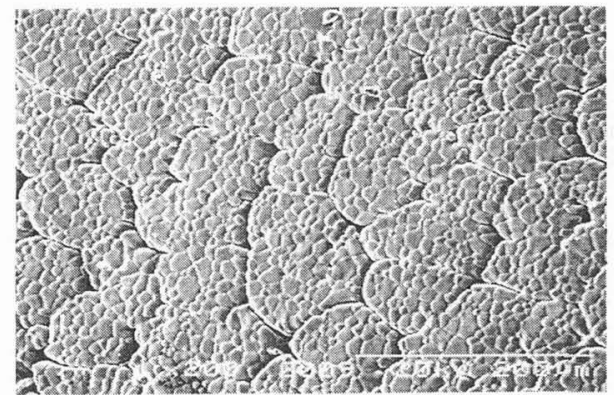

Fig. 3. SEM photograph of core surface (sintered at a normal $\mathrm{Zn}$ loss condition).

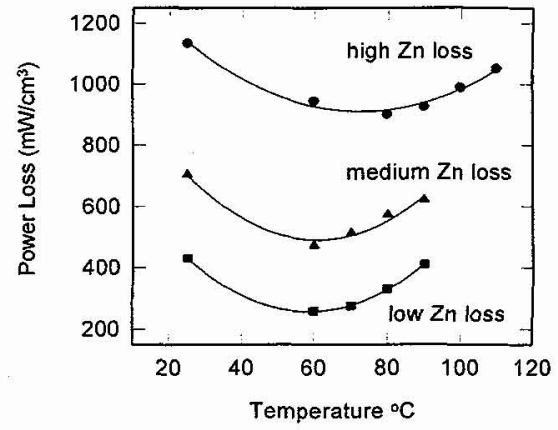

Fig. 4. The power loss characteristic at three different $\mathrm{Zn}$ loss conditions.

\section{References}

1) T. Nomura, Ferrites: Proceedings of The Sixth International Conference on Ferrites, p65-70 (1992)

2) R. Morineau and M. Paulus, IEEE Trans. Magn., vol. MAG-11, pp.1312-14 (1975)

3) T. Mochizuki, Ferrites: Proceedings of The Sixth International Conference on Ferrites, p53-58 (1992)

4) H. Tsunekawa, A. Makata, T. Kamijo, K. Okutani, IEEE Transactions on Magnetics, Vol. MAG-15, No. 6, p1855-57(1979) 